\title{
Epidemiological investigation of bluetongue virus antibodies in sheep in I ran
}

\author{
Mohammad Khezri ${ }^{1}$ and Seyed Mahmoud Azimi ${ }^{2}$ \\ 1. Agricultural and Natural Resources Research Center of Kurdistan, Kurdistan, Iran. \\ 2. Razi Vaccine and Serum Research Institute, Alborz, Iran. \\ Corresponding author: Mohammad Khezri, email:khezri1836@yahoo.com \\ Received:29-06-2012, Accepted: 10-08-2012, Published online: 27-12-2012
}

How to cite this article:

Khezri M and Azimi SM (2013) Epidemiological investigation of bluetongue virus antibodies in sheep in Iran, Vet World 6(3): 122-125, doi: 10.5455/vetworld.2013.122-125

\begin{abstract}
Aim: Bluetongue is a non-contagious, infectious viral disease of domestic and wild ruminants; which is believed to have originated in Africa. The epidemiology of Bluetongue virus infection is poorly defined in many parts of the world, including a wide range of Asia and the Middle East. This paper reports the results of a Bluetongue serological survey in sheep from some provinces of Iran during 2007-2008.
\end{abstract}

Material and Methods: A total of 996 sheep sera were collected from 8 provinces in Iran and tested for Bluetongue virus specific using c-ELISA.

Results: The results showed that the Bluetongue virus seroprevalence of sheep over the entire study areas was $34.93 \%$, with the highest and lowest prevalence seen in West-Azerbaijan (64.86\%) and Qom (12.1\%) areas respectively.

Conclusion: The results demonstrated a high prevalence of Bluetongue antibodies in Iranian sheep, giving serological evidence of extensive exposure to Bluetongue virus infection in some provinces of the country.

Keywords: antibodies, bluetongue virus, c-ELISA, Iran, seroprevalence

\section{I ntroduction}

Bluetongue virus (BTV) belongs to the genus Orbivirus in the family Reoviridae. The virus particle is non-enveloped, icosahedral in shape, and consists of a double-layered protein coat. At least 26 serotypes of the virus have been identified [1,2]. Bluetongue (BT) is on the Office international des epizootics (OIE) list of notifiable multi-species diseases because of its substantial economic impact and potential for rapid spread. Infection with BTV can cause severe hemorrhagic disease with high mortality rates in sheep and deer [3]. In sheep, the clinical signs may include fever, excessive salivation, depression, dyspnea and panting. Initially, animals have a clear nasal discharge, which becomes muco-purulent and dries to a crust around the nostrils at a later stage. The muzzle, lips, and ears become hyperemic, and the lips and tongue may swell severely. The tongue gets cyanotic and protrudes from the mouth occasionally. The coronary bands on the hooves are often hyperemic and painful, with progression to lameness and sloughing when driven. Pregnant ewes may abort their fetuses, or give birth to "dummy" lambs [4]. In sheep, the severity of disease varies with breed, virus strain, and environmental stresses, and morbidity rate can be as high as $100 \%$ in this species. Mortality rates are usually $0-30 \%$, but can reach 70\% in highly susceptible animals [4].

Hematophagous Culicoides insects transmit BTV from infected to susceptible ruminants, thus the global distribution of BTV coincides with the distribution of competent Culicoides insect vectors and climatic conditions promoting their proliferation [5,6]. Even though an orbivirus, direct transmission of BTV from vertebrate to vertebrate transplacentally and through semen has been demonstrated. Nonetheless, such transmission mechanisms are rare [7].

In the Mediterranean region, BT was reported first from Cyprus and Israel in 1943 but is thought to have occurred in the region as early as 1924. Six serotypes, namely BTV-2, $-4,-6,-9,-10$ and -16 , recurred at varying temporal intervals. BT is enzootic in Turkey, Syria, Israel and Egypt, thus making these countries a potential source of virus for the Westward located regions. There is evidence that outbreaks of BT are mediated by the transportation of infected midges from enzootic to non-enzootic areas by winds that seasonally prevail, and that this is the principal manner by which a fractured, but persistent cycle of BT is perpetuated around the Mediterranean Sea [8].

Diagnostics tests are a major component of the success of any surveillance system. A variety of serological tests are capable of detecting BTV specific antibodies. These include agar gel immunodiffusion (AGID), haemagglutination-inhibition (HI), complement fixation $(\mathrm{CF})$, serogroup-specific blocking or competitive enzyme-linked immunosorbent assays (c-ELISA), and serotype-specific serum neutralization (SN) tests [9]. Non-serological diagnostic tools include BTV 
Table-1. Prevalence of BTV antibodies in sheep from 8 provinces in I ran between 2007-2008

\begin{tabular}{lllcc}
\hline Province & Region & No. & Positive & Infection (\%) \\
\hline Ardabil & North West & 122 & 29 & 23.77 \\
E. Azerbaijan & North West & 198 & 79 & 39.89 \\
W. Azerbaijan & North West & 74 & 48 & 64.86 \\
Kurdistan & West & 151 & 63 & 41.72 \\
Ilam & West & 211 & 90 & 42.65 \\
Khuzestan & South West & 20 & 3 & 15 \\
Qom & Center & 149 & 18 & 12.1 \\
Fars & South & 71 & 18 & 25.35 \\
Total & & & & $\mathbf{3 4 . 9 3}$ \\
\hline
\end{tabular}

isolation, antigen and genome identification, RT-PCR is extensively used since it is rapid, can identify the serotype of the BTV strain [10]; and detects viral nucleic acid for up to 6 weeks and 6 months postinfection in experimentally infected sheep and cattle accordingly[11,12].

The OIE manual of diagnostic tests and vaccines for terrestrial animals recommends AGID, c-ELISA and RT-PCR as prescribed tests for international trade. However, AGID is known for cross-reactions with other Orbiviruses such as epizootic haemorrhagic disease virus (EDHV) [13], thus its use has declined over time and replaced with the easier to use, rapid, highly sensitive and specific c-ELISA [14,15]. Moreover, the c-ELISA has been reported to detect BTV antibodies from the 7th to 10th day post infection [16]. Although the SN test is in general recognized as the most sensitive and specific serological test for the detection of BTV antibodies in ruminants [17], its application in routine diagnosis impractical since the test is too cumbersome, time-consuming and involves testing for at least 24 serotypes per sample [15].

In Iran, approximately $37.4 \%, 34.1 \%$ and $24.7 \%$ of the livestock comprise sheep, goats and cattle respectively. Diseases of livestock are a threat to the wellbeing of the animal and human populations, and could have a devastating impact on the economy. Incidences of BTV occurrence have been documented in Iran, Pakistan, Saudi Arabia, Oman, Turkey, Yemen, India, Kuwait and the Middle East [18-26] in the past, but only a few studies from the region have been published recently.

The aim of this study was thus to estimate the prevalence of BTV antibodies in sheep from different provinces of Iran during 2007-2008.

\section{Materials and Methods}

Serum samples: Blood $(5 \mathrm{ml})$ drawn from the Jugular veins of 996 randomly selected sheep from 8 provinces of Iran (Table-1, Fig.1). Sera were harvested from clotted blood within $1 \mathrm{~h}$ by centrifugation and immediately stored at $-20^{\circ} \mathrm{C}$ prior analysis.

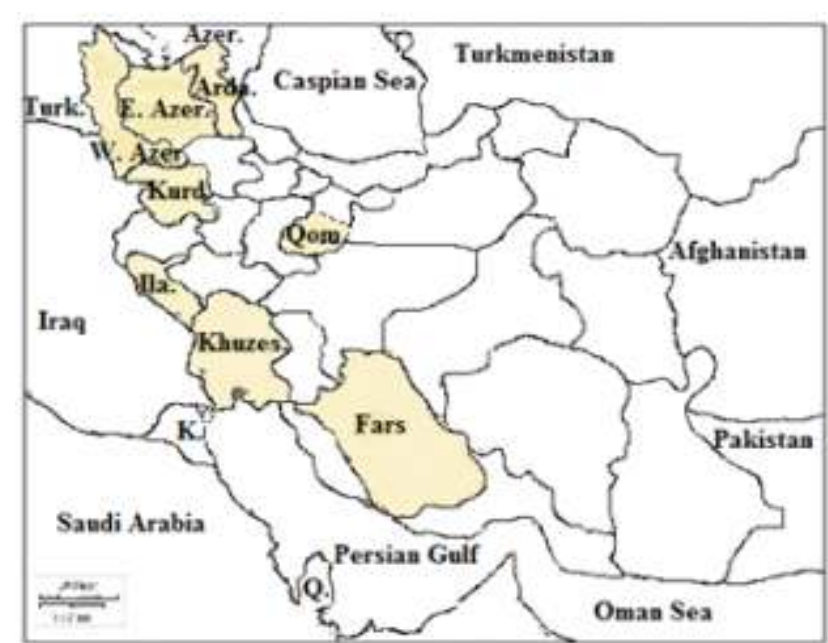

Figure 1. Map of Iran showing the location of areas where the present study was conducted

C-ELI SA: BTV antibodies in sera were detected using a commercial group specific competitive ELISA kit (VMRD Inc., Pullman, USA). The assay is based on a competition for binding to a VP7 antigen coated on the solid phase of the ELISA plate, between test sera antibodies and anti-VP7 MAb. Strong color development following addition of substrate indicates little or no blockage of monoclonal antibody binding and thus the absence of BT antibody in sample sera. Weak color development due to inhibition of the monoclonal antibody binding to the antigen on the solid phase indicates the presence of bluetongue antibodies in sample sera.

\section{Results}

The simplicity, sensitivity, specificity and rapidity of the c-ELISA made it ideal for use as a high throughput test in the study.

A combined BT seroprevalence among the provinces comprising the 2007-2008 sero surveillance was $34.93 \%$ (348/996 positive sera) (Table-1).

Prevalence of specific antibodies to BTV ranged between $12.1 \%$ and $64.86 \%$ among the provinces. West-Azerbaijan had the highest number of positive sheep $(64.86 \%)$, while Qom displayed the lowest infection rates $(12.1 \%)$.

\section{Discussion}

Iran is located in South West Asia. It is bound by Azerbaijan, Armenia, Turkmenistan and the Caspian Sea to the North, Afghanistan and Pakistan to the East, Iraq to the West, Turkey to the North-West, the Gulf of Persian and Oman Sea to the South (Figure1). There is a possibility that BTV can be transmitted by infected animals from neighboring countries which cross the borders into Iran.

BTV exists throughout many parts of the world including the Americas, Africa, southern Asia and northern Australia. While the virus is occasionally present in some areas in the southern part of Europe, recent developments indicate that it may be extending its range northwards into areas of Europe that were 
never affected. This is attributed mainly to climate and the northern expansion of the major old world vector, Culicoides imicola, which is an Afro-Asiatic species of biting midge [27].

Our study revealed a BT seroprevalence of $34.93 \%$ in sheep in Iran. Considering that no vaccination against BT is practiced, the findings clearly indicate that BTV infections occur in the country [28]. Higher seropositivity were recorded for India (62.69\%), Saudi Arabia (54.1\%) and Pakistan (48.8\%) accordingly [19, $26,29]$, while lower prevalence rates of $21.4 \%$ and $29.5 \%$ were reported for Kazakhstan and SouthEastern Turkey respectively [7,21]. Iran is thus immediately adjacent to the unstable BT zone involving Afghanistan, Iraq, Pakistan and Turkey [30].

The economy of the area is based on agriculture and domestic ruminants come into contact when grazing on extensive semi-arid rangeland pastures $[30,31]$. When taking into consideration the seasonal movements of different live animals, it is suggested that risk-based control measures be adopted [19]. Iran's strategic location in the South-East of Europe makes it an important potential source of BTV strains and serotypes that may spread to adjacent countries [27].The distribution and intensity of infection in regions of the continents is determined by the climate, geography and altitude, since these factors affect the occurrence and activity of the Culicoides vectors. The presence of susceptible mammalian hosts also play an important role [27]. Climate is a major risk factor as Culicoides require warmth and moisture for breeding and calm, and warm humid weather for feeding [27]. A cold winter or a dry summer can markedly reduce vector numbers and risk of disease occurrence. Moisture may be in the form of rivers and streams or irrigation; but, rainfall is the predominant influence and rainfall in the preceding months is a major determinant of BTV infection. Optimal temperatures are also essential and in endemic areas, temperatures for survival of the adults and larvae should constantly be above a mean of $12.5^{\circ} \mathrm{C}$ for the cooler months and in the range of $18^{\circ} \mathrm{C}$ to $30^{\circ} \mathrm{C}$ in summer and autumn. These values guarantee optimum recruitment of adults and activity $[32,33]$.

Cattle and sheep displaying varying clinical signs suggestive of BTV infection were encountered in Iran. The varying disease severity could be attributed to animal species and breeds, environmental conditions, viral strains and level of viremia. Nonetheless the clinical cases were not corroborated by laboratory tests and the animals could have suffered from diseases other than BT [34].

The highest prevalence was in West-Azerbaijan $(64.86 \%)$ and the lowest infection rates were observed for Qom (12.1\%). The West-Azerbaijan seroprevalence reported in this study $(64.86 \%)$ in markedly higher than that previously recorded by other workers for the same province (34.7\%) [6]. The increased current figured could be due to the fact that more samples were tested, or signal increased BTV infection rates. East-Azarbaijan province in the North-West part of Iran was previously reported to have a seropositivity of 76.44\% [35], while our study showed a reduced rate of $39.89 \%$ for the same area. Sero-surveillance studies have nonetheless indicated a general increase in BT antibody levels in the North-West parts of the country [6].

Previous studies employing BT c-ELISA have indicated seroprevalence of $51.6 \%, 45.9 \%, 2.13 \%$ and $100 \%$ for sheep, cattle and camel in the central (Isfahan), West (Kurdistan) and South-East (Kerman) of Iran respectively [31,36,37,38].

\section{Conclusions}

BTV seroprevalence has never been reported in many areas of Iran encompassing Ardabil, Khuzestan, Qom and Fars. As far as we know, this is the first study investigating the prevalence of antibodies to BTV in sheep in these provinces of the country. Our results demonstrated a high prevalence of BT antibodies in sheep in Iran, providing serological evidence of exposure to BTV. In the absence of animal movement restrictions in the region and within the country, animal transportation possess a huge risk for BT outbreaks. Consequently, a well-defined control strategy for preventing and controlling BTV spread should not only be based on vaccination and vector eradication but also include restriction of animal movements between countries in the region, and within Iran. BTV is widespread in some areas of Iran with the possibility of endemic icy, warranting further research.

\section{Author's contribution}

SMA implemented the study design and test samples. MK analyzed the data, drafted and revised the manuscript. Both authors read and approved final manuscript.

\section{Acknowledgments}

This study was supported with a grant of Razi Vaccine and Serum Research Institute.

\section{Competing interests}

Authors declare that they have no competing interest.

\section{References}

1. Lee, F., Ting, L.J., Jong, M.H., Chang, W.M., Wang, F.I. (2010). Subclinical bluetongue virus infection in domestic ruminants in Taiwan. Vet. Microbiol., 142: 225-231.

2. Schwartz-Cornil, I., Mertens, P.P.C., Contreras, V., Hemati, B., Pascale, F., Breard, E., Mellor, P.S., MacLachlan, N.J., Zientara, S. (2008). Bluetongue virus: virology, Pathogenesis and immunity. Vet. Res., 39: 46-61.

3. Rodriguez-Sanchez, B., Gortazar, C., Ruiz-Fons, F., Sanchez-Vizcaino, J.M. (2010). Bluetongue virus serotypes 1 and 4 in red deer, Spain. Emerg. Infect. Dis., 16: 518-520.

4. OIE, (2006). Bluetongue detected for the first time in Northern Europe. In, WorldOrganization for Animal Health. Bluetongue detected for the first time in Northern Europe. Paris, http://www.oie.int/for-the-media/press releases/detail/article/bluetongue-detected-for-the-first time-in-northern-europe/

5. Jafari-Shoorijeh, S., Ramin, A.G., Maclachlan, N.J., Osburn, 
B.I., Tamadon, A., Behzadi, M.A., Mahdavi, M., Araskhani, A., Samani, D., Rezajou, N., Amin-Pour, A. (2010). High seroprevalence of bluetongue virus infection in sheep flocks in West Azerbaijan, Iran. Comp. Immunol. Microbiol. Infect. Dis.,33: 243-247.

6. Lundervold, M., Milner-Guilland, E.J., O'Callaghan, C.J., Hamblin, C. (2003). First evidence of bluetongue virus in Kazakhstan. Vet. Microbiol., 92: 281-287.

7. Maclachlan, N.J. (2011). Bluetongue: History, global epidemiology, and pathogenesis. Prev. Vet. Med.,102: 107111.

8. OIE, (2008). Bluetongue, Manual of Diagnostic Tests and Vaccines for Terrestrial Animals (mammals, birds and bees). In, Vol. 1, Paris, pp. 195-210. www.oie.int.

9. Afshar, A. (1994). Bluetongue: laboratory diagnosis. Comp. Immunol. Microbiol. Infect. Dis., 17:221-242.

10. Billinis, C., Koumbati, M., Spyrou, V., Nomikou, K., Mangana, O., Panagiotidis, C.A., Papadopoulos, O. (2001). Bluetongue virus diagnosis of clinical cases by a duplex reverse transcription-PCR: a comparison with conventional methods. J. Virol. Methods, 98: 77-89.

11. Katz, J., Alstad, D., Gustafson, G., Evermann, J. (1994). Diagnostic analysis of the prolonged bluetongue virus RNA presence found in the blood of naturally infected cattle and experimentally infected sheep. J. Vet. Diag. Inves., 6: 139142.

12. MacLachlan, N.J., Nunamaker, R.A., Katz, J.B., Sawyer, M.M., Akita, G.Y., Osburn, B.I., Tabachnick, W.J. (1994). Detection of bluetongue virus in the blood of inoculated calves: comparison of virus isolation, PCR assay, and in vitro feeding of Culicoides variipennis. Arch. Virol., 136: 1-8.

13. Afshar, A., Thomas, F.C., Wright, P.F., Shapiro, J.L., Anderson, J. (1989). Comparison of competitive ELISA, indirect ELISA and standard AGID tests for detecting bluetongue virus antibodies in cattle and sheep. Vet. Rec., 124: 136-141.

14. Della-Porta, A.J., Parson, I.M., McPhee, D.A. (1985). Problems in the interpretation of diagnostics tests due to cross reactions between orbiviruses and broad serological responses in animals. Prog. Clin. Biol. Res., 178: 445-453.

15. Reddington, J.J., Reddington, G.M., MacLachlan, N.J. (1991). A competitive ELISA for detection of antibodies to the group antigen of bluetongue virus. J. Vet. Diag. Inves., 3: 144-147.

16. MacLachlan, N.J., Pearson, J.E. (2004). Bluetongue. Proceedings of the Third International Symposium Taormina, 26-29 October 2003. Vet. Ital., Part 2. 40(3), pp. 417-703.http://www.oie.int/doc/ged/D6497.PDF

17. Sperlova, A., Zendulkova, D. (2011). Bluetongue: a review. Vet.Med., 56: 430-452.

18. Afshar, A., Kayvanfar, H. (1974). Occurrence of precipitating antibodies to bluetongue virus in sera of farm animals in Iran. Vet. Rec., 94: 233-235.

19. Akhtar, S., Djallem, N., Shad, G., Thiemo, O. (1997). Bluetongue virus seropositivity in sheep flocks in North West Frontier Province, Pakistan. Prev. Vet. Med., 29: 293298.

20. Al-Busaidy, S.M., Mellor, P.S. (1991). Epidemiology of bluetongue and related orbiviruses in the Sultanate of Oman. Epidemio. Infect., 106: 167-178.

21. Gür, S. (2008). A serologic investigation of bluetongue virus (BTV) in cattle, sheep and gazella subgutturosa subgutturosa in southeastern Turkey. Trop. Anim. Health Prod., 40:217221.

22. Maan, S., Maan, N.S., Nomikou, K., Batten, C., Antony, F., Belaganahalli, M.N., Samy, A.M., Reda, A.A., Al-Rashid,
S.A., El Batel, M., Oura, C.A., Mertens, P.P. (2011). Novel bluetongue virus serotype from Kuwait. Emerg. Infect. Dis., 17: 886-889.

23. Sreenivasulu, D., SubbaRao, M.V., Reddy, Y.N., Gard, G.P. (2004). Overview ofbluetongue disease, viruses, vectors, surveillance and unique features: the Indiansubcontinent and adjacent regions. Vet. Ital., 40: 73-77.

24. Stanley, M. (1990). Prevalence of bluetongue precipitating antibodies in domesticatedanimals in Yemen Arab Republic. Trop. Anim. Health Prod., 22: 163-164.

25. Taylor, W.P., Sellers, R.F., Gumm, I.D., Herniman, K.A., Owen, L. (1985). Bluetongueepidemiology in the Middle East. Prog. Clin. Biolog. Res., 178: 527-530.

26. Yousef, M.R., Al-Eesa, A.A., Al-Blowi, M.H. (2012). High seroprevalence of Bluetonguevirus antibodies in Sheep, Goats, Cattle and Camel in different districts of SaudiArabia. Vet. World, 5: 389-393.

27. Purse, B.V., Mellor, P.S., Rogers, D.J., Samuel, A.R., Mertens, P.P., Baylis, M. (2005).Climate change and the recent emergence of bluetongue in Europe. Nature Rev. Microbiol.,3: 171-181.

28. Mellor, P.S., Widmann, E.J. (2002). Bluetongue virus in the Mediterranean Basin. Vet. J., 164: 20-37.

29. Malik, Y.P.S., Thakare, V., M., K. (2010). Serological detection of bluetongue: comparisonof competitive ELISA with other routinely used immunoassays. Indian J. Anim. Sci., 80: 1059-1061.

30. Mellor, P.S., Carpenter, S., Harrup, L., Baylis, M., Mertens, P.P. (2008). Bluetongue inEurope and the Mediterranean Basin: history of occurrence prior to 2006. Prev. Vet. Med., 87:4-8.

31. Mahdavi, S., Khedmati, K., PishraftSabet, L. (2006). Serologic evidence of bluetongueinfection in one-humped camels (Camelusdromedarius) in Kerman Province, Iran. Iranian J.Vet. Res., 7: 85-87.

32. Paweska, J.T., Venter, G.J., Mellor, P.S. (2002). Vector competence of South AfricanCulicoides species for bluetongue virus serotype 1 (BTV1) with special reference to theeffect of temperature on the rate of virus replication in C. imicola and C. bolitinos (Diptera:Ceratopogonidae). Med. Vet. Entomol., 16: 10-21.

33. Ward, M.P., Thurmond, M.C. (1995). Climatic factors associated with risk of seroconversionof cattle to bluetongue viruses in Queensland. Prev. Vet. Med.,24: 129-136.

34. Momtaz, H., Nejat, S., Souod, N., Momeni, M., Safari, S. (2011). Comparisons ofcompetitive enzyme-linked immunosorbent assay and one step RT-PCR tests for thedetection of Bluetongue virus in south west of Iran. African J. Biotechnol., 10: 6857-6862.

35. Hasanpour, A., Mosakhani, F., Mirzaii, H., Mostofi, S. (2008). Seroprevalence ofBluetongueVirus Infection in Sheep in East-Azerbaijan Province in Iran. Res. J. Biol. Sci., 3: $1265-1270$.

36. Noman, V., KargarMoakhhar, R., Shah Moradi, A.H., Hydari, M.R., Tabatabaei, J. (2006).A Seroepidemiological survey for bluetongue virus antibody in sheep and goats of Isfahanprovince, Iran. http://77.104.98.73:880/cgibin/isis $3 \mathrm{w} . e x e ?$ rec_id $=002016 \&$ database $=$ agris $\&$ search_type $=$ link $\&$ table $=$ mona $\&$ backpath $=/$ agris $/$ mona\&lang=eng\&format name $=$ EFMON .

37. Khezri, M. (2012). Seroprevalence of Bluetongue Virus Antibodies in Sheep in Kurdistan Province in West of Ian. IJAVMS., 6: 183-188.

38. Mozaffari, A.A., Khalili, M., Yahyazadeh, F. (2010). A serological investigation ofbluetongue virus in cattle of south-east Iran. Vet. Ital., 48: 41-44. 